Małgorzata Zajaczkowski*

\title{
EXTERNAL AND INTERNAL LIBERALIZATION THAT ENP PROMOTES AS TRANSMISSION BELTS OF DEMOCRATIZATION AND POLITICAL STABILITY: SUCCESS AND FAILURE REVISITED - THE SOUTHERN DIMENSION ${ }^{1}$
}

\section{Introduction}

Revolutionary turmoil in the Southern Mediterranean region and slow reforms in most partner countries have put at risk the continuation of the process of liberalization and modernization in the Mediterranean economies. Against this background the European Commission decided to revise its program of the European Neighborhood Policy (ENP) and launched a new formula initiative called the Union for the Mediterranean. The new approach was based on the idea of 'partnership for democracy and shared prosperity' and was to revisit the idea of Euro-Mediterranean Partnership enacted in mid-1990. The EU assumed greater political and financial support for those countries who managed to implement better political and economic reforms and pro-democratic changes ${ }^{2}$. The conditionality formula based on "more for more" basis was to be an incentive for building a long-perspective initiative of deeper economic reforms in the partner countries.

The aim of the paper is to analyze the effects of the ENP on the Southern Mediterranean neighbors in the context of economic liberalization and pro-democratic changes. The paper comprises two problems. First it is an issue of economic development and trade liberalization which the ENP is offering through deeper integration

* Collegium of Socio-Economics, Warsaw School of Economics.

1 The paper was prepared under the research grant of the Polish National Science Center (NCN) entitled European Neighborhood Policy: Multi-Level Governance, The Reform Process and the Prospect of Enhanced Cooperation in the Region, OPUS/HS5, No. 2013/09/B/HS5/04534.

2 Joint Communication to the European Council, the European Parliament, the Council, the European Economic and Social Committee and the Committee of the Regions, A Partnership for Democracy and Shared Prosperity with the Southern Mediterranean, COM(2011) 200 final, Brussels, 8.03.2011. 
with the EU and market-oriented regulations. Second dilemma concerns the process of democratic changes that the EU has committed to promote. Due to the highly vulnerable approach of the Mediterranean states to the concept of democratization, it was replaced by the idea of governance. For this purpose, there were presented general trends of the Mediterranean societies in their approach to that notion.

\section{Foundations of the ENP}

The European Neighborhood Policy (ENP) was launched in 2004 with the aim of building new political and economic relations between the EU and its Southern and Eastern neighboring countries through supporting introduction of reforms and systemic changes in the partner countries. In the South, the initiative covered ten countries: Algeria, Egypt, Israel, Jordan, Lebanon, Libya, Morocco, Palestine, Syria and Tunisia and in the East six states: Armenia, Azerbaijan, Belarus, Georgia, Moldova and Ukraine. The main objective of the ENP was to avoid the emergence of new dividing lines between the enlarged $\mathrm{EU}$ and its neighbors by engaging in the negotiation of reform priorities leading to good governance, rule of law, trade liberalization and civil society representation in the partner countries. The ENP was to go beyond the traditional financial assistance provided to the neighboring countries and was assumed to be better suited to the challenges in particular regions. Under the ENP, several sets of priorities both for enhancing cooperation between the EU and Mediterranean partners and among the partners themselves have been identified. The highest priority was granted to good governance, democracy, rule of law and human rights. The other covered economic development, security dimension, migration and mobility ${ }^{3}$.

The emergence of the Southern dimension of the ENP has put a new challenge to the existing Union for the Mediterranean (UfM), which was established upon the initiative of French President Nicolas Sarkozy in 2008. The UfM was built upon the foundations of the Euro-Mediterranean Partnership (EMP) which was laid down within the framework of the Barcelona Process in 1995. Under the EMP formula, there was introduced an ambitious long-lasting program on political, economic and cultural co-operation between the $15 \mathrm{EU}$ Member states and 12 Mediterranean

3 European Commission, European Neighborhood Policy and Enlargement Negotiations, https://ec.europa. eu/neighbourhood-enlargement/neighbourhood/overview_en [access 2.03.2016].

4 J. Wouters, S. Duquet, The Arab Uprisings and the European Union: In Search of a Comprehensive Strategy, "CLEER Working Papers" 3, 2013, p. 21. 
partners with much focus on democratization and sustainable socio-economic prosperity. The cooperation was reinforced by initiating a free trade area between the EU and the partners, which was to be implemented by 2010 through Euro-Mediterranean Association Agreements with each of them. Because of the mass criticism and unsatisfactory results, the Barcelona Process was considered a failure at its tenth anniversary in $2005^{5}$.

The new impetus in Euro-Med relations brought the Union for the Mediterranean in 2008. The initiative was to reinforce the Southern dimension of the ENP and put a clear distinction between the Eastern and Southern neighbors ${ }^{6}$. It was also an indicator that the approach "one size fits all" applied in the ENP was inadequate to the situation and showed little added value compared to other forms of more traditional bilateral assistance ${ }^{7}$. The new initiative was equipped with its own intergovernmental set-up and a limited number of political and economic objectives, which meant short term goals of enhancing economic relations and European security ahead of addressing local socio-economic problems ${ }^{8}$.The ENP program reinforced by the UfM was to be pursued in two ways: first in the multilateral and second, bilateral dimension. The multilateral perspective is related to the UfM and its predecessor - the Barcelona Process. The bilateral dimension is complemented by the Association Agreement (AAs) undertaken within the Barcelona Process and the ENP Action Plans within the ENP.

Bilateral relations under the Euro-Med partnership are based on the Euro-Mediterranean Association Agreement and the ENP Action Plans. Both they are the good examples of a multilateral framework complemented with bilateral tools. The first generation of EC Cooperation Agreements had been in place prior to the Barcelona Summit in 1995 and were renegotiated and replaced by AAs, concluded between 1995 and 2005 within the EMP's framework and later also under the ENP Action Plans'. The ENP framework includes 10 partner countries: Algeria, Egypt, Israel, Jordan, Lebanon, Libya, Morocco, Palestine, Syria and Tunisia. So far there have been agreed seven Action Plans with Egypt, Israel, Jordan, Lebanon, Morocco, the Palestinian Authority and Tunisia. Bilateral Agreements were suspended with Libya and Syria

5 R.A. Sarto, T. Schumacher, From EMP to ENP: What's at Stake with the European Neighborhood Policy Towards the Southern Mediterranean?, "European Foreign Affairs Review" 2005, pp. 17-38.

6 The Eastern dimension of the ENP was reinforced by the initiative 'Eastern Partnership' which was launched in 2009.

7 W. Koeth, The 'Deep and Comprehensive Free Trade Agreements': An Appropriate Response by the EU to the Challenges in Its Neighbourhood?, European Institute of Public Administration, 2014, p. 24.

8 J. Wouters, S. Duquet, The Arab, op.cit., p. 22.

9 Ibidem, p. 23. 
and have yet to be resumed ${ }^{10}$. Palestine has concluded its Interim Association Agreement on Trade and Cooperation with the EU in 1997 and the additional Agreement for further liberalization of agricultural products entered into force in $2012^{11}$. Out of ten Mediterranean partners, seven are actually involved in the ENP and they are parties to the working Action Plan ${ }^{12}$.

\section{Trade Liberalization Agreements}

Economic relations between the Mediterranean partners and the EU were an essential part of the EMP framework and remained as such within the ENP. The integration of the Mediterranean markets with the European economy was conditioned by the progress of the partner countries, which meant that only profound reforms would bring the neighboring countries closer to the European market. The only issue that has changed over the time was a much lesser pressure on the width and depth of the reforms among the Mediterranean partners.

The establishing of a free trade area (FTA) by 2010 was a key objective within the Barcelona Process. Bilateral FTAs were included in each AAs and the negotiation position of the partners depended on the economic development of a country and its profile. However, final results did not meet the initial goals. First, the coverage of the FTA was restricted to the trade in goods and second, only limited number or countries engaged in the development of their FTAs with the EU but also with other partner countries in the region ${ }^{13}$. They included Egypt, Jordan, Morocco and Tunisia (Agadir Agreement, 2001).

The most advanced partners which have managed to introduce substantial reforms under the Euro-Mediterranean AAs have been offered a new formula of a free trade agreement. The second generation Deep Comprehensive Free Trade Agreement (DCFTA) was introduced, which was designed as an instrument enabling the countries

\footnotetext{
10 Negotiations with Algeria have not brought about any Action Plan so far. In turn, Libya has not decided to become a full member of the Euro-Mediterranean Partnership and accepted its role as an observer. Because of the military turmoil Syria has not yet signed an AA, which is a condition for agreeing to an ENP Action Plan. R. Aliboni, Evaluating the Political and Strategic Dimensions, [in:] The European Neighbourhood Policy and the Southern Mediterranean Drawing from the Lessons of Enlargement, eds. M. Comelli, A. Eralp, C. Ustun, Middle East Technical University Press, Ankara 2009, p. 14.

11 European Commission, Trade Policy, http://ec.europa.eu/trade/policy/countries-and-regions/countries/palestine/\#footnote-1 [access 3.03.2016]

12 R. Aliboni, Evaluating, op.cit., p. 14.

13 J. Wouters, S. Duquet, The Arab, op.cit., p. 37.
} 
(both from the Eastern and Southern dimension of the ENP) to create better integration of their economies with the EU single market. In December 2011, the EU decided to launch negotiations with Jordan, Egypt, Tunisia and Morocco. The DCFTAs consist of two parts: first - tariff reduction which is built on WTO commitments and second - adoption of the EU trade acquis going beyond tariff reductions to cover more extensively the dimensions of investment protection, public procurement and competition policy. They cover all trade-related areas such as services, intellectual property rights, customs, public procurement, energy-related issues, competition, etc.

Although the scale and the content of the reforms undertaken by Jordan, Egypt, Tunisia and Morocco were poor, the EU acknowledged it to be sufficient for launching a new set of negotiations under the DCFTA provisions. Fortunately, the countries were members of the WTO which allowed them to avoid additional differences during the negotiations.

With regard to Morocco, the most advanced partner in terms of political stability and economic reforms, DCFTA negotiation was suspended in 2014, just after the year of considerable progress in talks. In case of Tunisia the first round of negotiation was launched in April 2016. Discussions were concentrated on agriculture, services and sustainable development. The EU-Tunisia Association Agreement entered into force in 1998 and created a free trade agreement (FTA). However, due to the difficulties in implementation the parties decided to revisit the agreement. In 2011 the EU started to launch negotiation with Jordan. The plan was to build the new agreement on the existing FTA, which entered into force in 2002 under the EU-Jordan AA. For Egypt, the situation was much more difficult. Because of the post-Arab Spring political turmoil, the government was not yet ready for opening talks with the EU under the DCFTA.

Taking into account the European Commission's statement on the ENP as a "single, inclusive, balanced and coherent policy framework" 14 it is evident to notice growing differences between the partners from the Southern and Eastern dimension of the ENP. The Eastern neighboring countries are much more prone to sign the DCFTA than the Mediterranean ones. The EU declared that the Southern DCFTAs' will have the same scope and goals as the DCFTA's signed with the Eastern partners. Thus, all agreements were to be developed in the same ENP's framework with those neighboring partners which would manage to implement and sustain its provisions (in 2014 the DCFTAs were signed with Ukraine, Moldova and Georgia). The EU Commission stated that certain aspects of the EU-Ukraine DCFTA "can serve as a model for other ENP partners in the future", which means that the negotiating directives for

14 Council of the EU, Council Conclusions on the ENP, 851st External Relations, Brussels, 18.02.2008. 
the Mediterranean DCFTAs are very similar to those adopted for the Eastern countries ${ }^{15}$. The problem is that the Mediterranean countries have divergent systems of governance and institutions which would not let them easily implement the provisions included in the DCFTA.

Most of the Mediterranean partner countries have concluded AAs with the EU, which cover trade in industrial goods with some additional protocols on liberalization in agriculture commodities (the AAs were entered into force with Algeria in 2005, Egypt in 2004, Israel in 2000, Jordan in 2002, Lebanon in 2006, Morocco in 2000, Palestine Interim Agreement in 1997 and Tunisia in 1998). However, for the time being there has been little chance to implement the provisions of the DCFTA even in the most advanced Southern partners. The provisions existing under the AAs are very difficult to include in the new generation DCFTA agreements. The problems on reducing the tariff barriers for industrial and agriculture goods are encountered in Morocco and Egypt.

\section{Democratization vs. Governance}

The ENP has put far more emphasis on democracy, human rights and sustainable development compared to previous initiatives such as the EMP and the Barcelona Declaration ${ }^{16}$. The revised ENP program established in 2011 was based on the principle of positive conditionality: the more governments in neighboring countries implement reforms in the sectors outlined in the EU strategy paper, the more assistance the EU will offer. The emphasis was put on the promotion of democracy and the support for democratization processes, reinforcing the rule of law, improving the respect of human rights, judicial reform, administrative capacity-building, fighting corruption and economic modernization ${ }^{17}$. Alongside the ENP's Action Plans, the EU established specific human rights sub-committees with Southern partners (except Israel) to benchmark and monitor the progress in democracy and human rights preservation. By introducing the idea of "joint ownership", the EU underlined the sovereign responsibility of their neighbors to proceed with reforms and pro-democratic

15 G. Loo, Enhancing the Prospect Sot the EU's Deep and Comprehensive Free Trade Areas in the Mediterranean: Lessons from the Eastern Partnership, Centre for European Policy Studies, CEPS Commentary, 24.06.2015, p. 2.

16 N. Tocci, J.P. Cassarino, Rethinking the EU's Mediterranean Policies Post - 1/11, "IAI Working Papers" No. 11/06, Istituto Affari Internazionali, 6.03.2011, p. 4.

17 S. Blockmans, The ENP and 'More for More' Conditionality: Plus Que ça Change ..., "Cleer Working Papers" 3, 2013, p. 54. 
changes. The EU wanted to encourage the partners to introduce substantial changes and enter the path of democratic changes.

However, the problem of democratization is for the Mediterranean countries a serious one. They are very sensitive to external forces tending to forge democratization in their homeland. They basically reject any demands for democratic reforms, which they treat as an interference in their home affairs ${ }^{18}$. Therefore, the Action Plan formula within the ENP based on a "joint ownership" assumes that democratic reforms in the ENP partner countries may be perceived as not being imposed from the outside but as with domestic or local origins. Thus, the EU should not 'impose' but 'support the region's own reforms' ${ }^{19}$. In such a situation, a good solution is to replace the concept of democratization by a notion of governance. It is much more acceptable for the Southern partners and is not directly related to the Western-oriented concept of democratization.

The EU widely started to apply the notion of governance together with the launch of the ENP in 2004. Thus, the ENP focused explicitly on political reforms and 'good' governance which has shifted the EU's attention to constitutional, electoral, judicial, governance and civil society areas ${ }^{20}$. The EU's definition of governance is very broad and it includes respect of human rights and fundamental freedom, support for democratization processes, rule of law, independent judicial system, access to information, accountability of relevant institutions, human safety, management of migratory flows, effective institutions, access to basic social services, sustainable management of natural and energy resources and of the environment, and the promotion of sustainable economic growth and social cohesion in a climate conducive to private investment ${ }^{21}$. The EU assumes that all the aspects of governance should be integrated into development strategies, which is a substance of the ENP Action Plans.

The concept of governance used by the EU conforms with the one developed within the World Bank. It has elaborated a long-standing research project to develop cross-country indicators of governance in selected countries and regions. Indicator

18 M. Comelli, M.C. Paciello, The ENP's Potential for Reform in the Southern Mediterranean: A Cost/ Benefit Analysis, [in:] The European Neighborhood Policy and the Southern Mediterranean, eds. M. Comelli, A. Eralp, C. Ustun, Middle East Technical University Press, Ankara, Turkey 2009, p. 54.

19 B. Ferrero-Waldner, The European Commissioner for External Relations and European Neighbourhood Policy, The Middle East in the EU's External Relations, Madrid 11.01.2007, http://europa.eu/rapid/ press-release_SPEECH-07-7_en.htm [access 4.03.2016].

20 G. Pace, The Notion of Governance in the South Mediterranean Regions, p. 17, http://www.cnr.it/istituti/Allegato_47006.pdf?LO... [access 2.03.2016].

21 Communication from the Commission to the Council, the European Parliament, the European Economic and Social Committee and the Committee of the Regions, Governance in the European Consensus on Development - Towards a Harmonized Approach Within the European Union, Brussels, 30.8.2006. 
of Worldwide Governance (IWG) - a tool for assessing the level and quality of governance was created for that purpose ${ }^{22}$. The IWG consists of six composite indicators of broad dimensions of governance covering over 200 countries since 1996: voice and accountability, political stability and lack of violence, government effectiveness, regulatory quality, rule of law, and control of corruption ${ }^{23}$. Using the IWG data for Mediterranean countries it may be a useful study of their political and socio-economic situation by indicating some general trends in the Mediterranean societies in their approach to that notion of governance. Every of the six indicators has its own explanation and references to the broader definition of governance proposed by the World Bank ${ }^{24}$.

The indicators were gathered on the basis of over dozens individual data sources (depending on the country) provided by a variety of survey institutes, think tanks, non-governmental organizations, international organizations, and private sector firms over the period 1996-2015. Each of the surveyed countries is measured on a scale from approximately -2.5 up +2.5 and each of them receives an estimation of governance based on a civil society and private entities perceptions. The WGI is not a perfect or universal tool for measuring the level of governance. Each of the estimate contains some margin of errors, which reflects the inherent difficulties in measuring governance by using these kinds of data ${ }^{25}$. However, it can play some useful role in terms of civil society and private entities' perceptions for six dimensions of governance.

The surveys of Mediterranean partner countries cover 9 out of 10 ENP states. The only partner for whom data have not been gathered was Palestine. The problem lies in the lack of recognition of the State of Palestine and different individual positions of the member states of the World Bank and the EU towards this territory.

22 Worldwide Governance Indicator, http://info.worldbank.org/governance/wgi/index.aspx\#home [access 3.03.2016]

23 D. Kaufmann, A. Kraay, M. Mastruzzi, The Worldwide Governance Indicators: Methodology and Analytical Issues, September 2010, http://info.worldbank.org/governance/wgi/pdf/WGI.pdf [access 9. 03.2016].

24 1. Voice and accountability. It indicates the citizens' perceptions on the ability to participate in the elections. It also examines the freedom of expression, freedom of association and free media. 2. Political stability and absence of violence. It measures perceptions of the likelihood of political instability or politically-motivated violence, including terrorism. 3. Government effectiveness. It refers to the perceptions of a quality of public services, the quality of the civil service and the degree of its independence from political pressures. It captures the quality of policy formulation and implementation, and the credibility of the government's commitment to such policies. 4. Regulatory quality. It is about the perception of the ability of the government to formulate and implement sound policies and regulations that permit and promote private sector development. 5. Rule of law. It refers to the perception of respecting of law, in particular the quality of contract enforcement, property rights, the police and the courts. 6. Control of corruption. It is the perception of the extent to which public power is exercised for private profits, including both petty and grand forms of corruption.

25 D. Kaufmann, A. Kraay, M. Mastruzzi, The Worldwide, op.cit. 
In the first dimension 'Voice and Accountability' (Figure 1) the best results were achieved in Israel for each period and Tunisia with substantial improvement in 2015. Other countries have gained poor outcomes with the predominant position of Syria and Libya.

Figure 1. Voice and Accountability

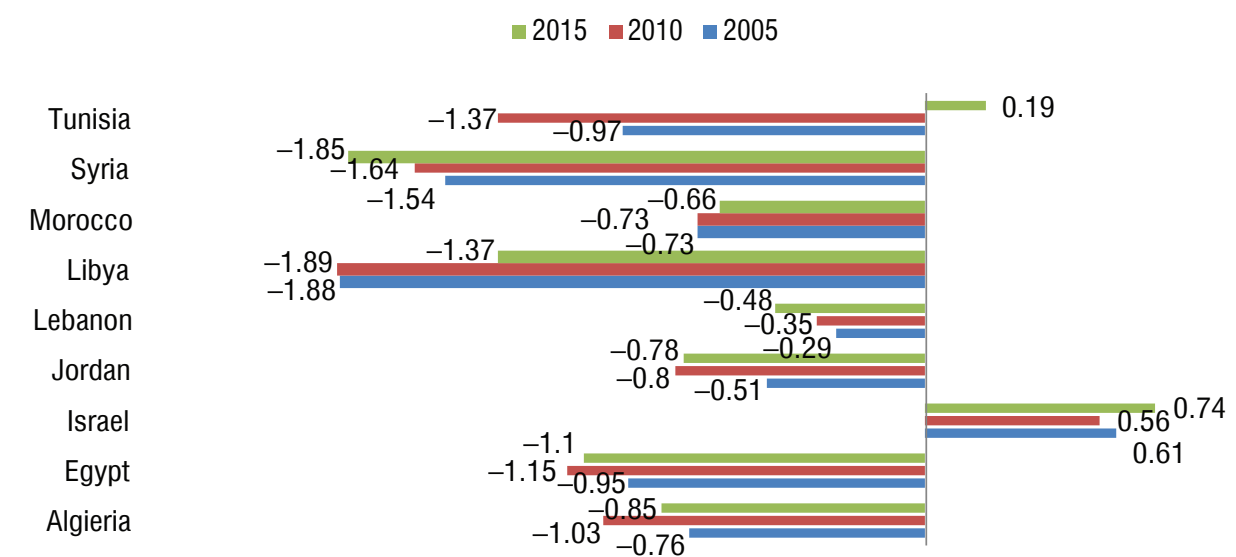

Source: own study based on the Indicator of Worldwide Governance http://info.worldbank.org/governance/ wgi/index.aspx\#home

Figure 2. Political Stability and Absence of Violence/Terrorism

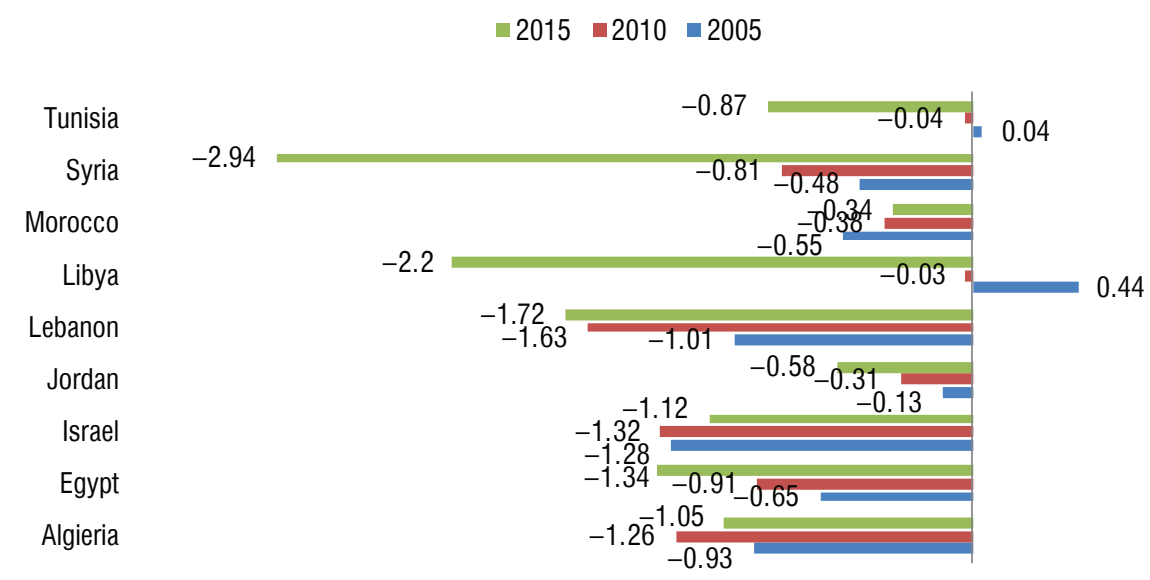

Source: own study based on the Indicator of Worldwide Governance http://info.worldbank.org/governance/ wgi/index.aspx\#home 
In the section 'Political Stability and Absence of Violence/Terrorism' (Figure 2) all states experienced threats to their internal and external security. With small positive exceptions in case of Tunisia and Libya (2005) the rest have been affected by gradual deterioration of their security.

Taking into account the indicator of Government Effectiveness (Figure 3) the best outcomes have been achieved by three countries: Israel, Tunisia and Jordan in all examined periods. Except Syria and Libya, which are plagued by widespread military conflicts, the remaining countries have reached meager results.

\section{Figure 3. Government Effectiveness}

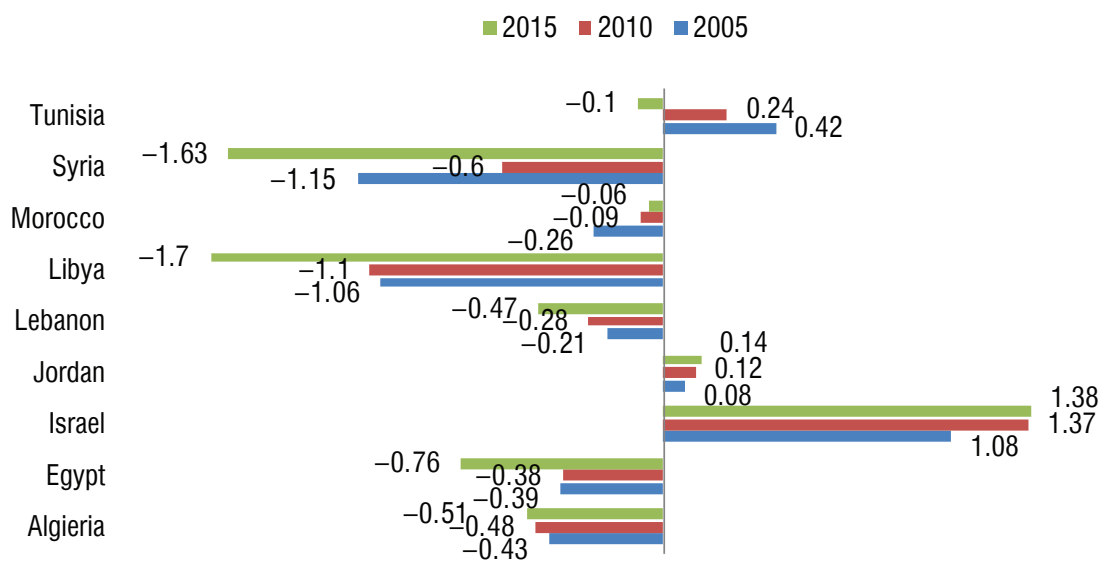

Source: own study based on the Indicator of Worldwide Governance http://info.worldbank.org/governance/ wgi/index.aspx\#home

Regarding the 'Regulatory Quality' (Figure 4), the most satisfied with their legislative and executive authority were citizens and private sector from Israel and Jordan. Some positive symptoms were noted in 2010 in Lebanon and much improvement was noticeable in the same year in Tunisia, Morocco and Egypt. Unfortunately, due to the event of $11 / 2001$, the situation has reversed and many regulations have been tightened up again.

In the field of 'Rule of Law' (Figure 5) the same trend appeared as in the case of 'Regulatory Quality'. Israel and Jordan preserved the highest position with positive estimations while the remaining partners have noted unsatisfactory results. The only exception was Tunisia in the first decade, but its situation has deteriorated in the next years. 
Figure 4. Regulatory Quality

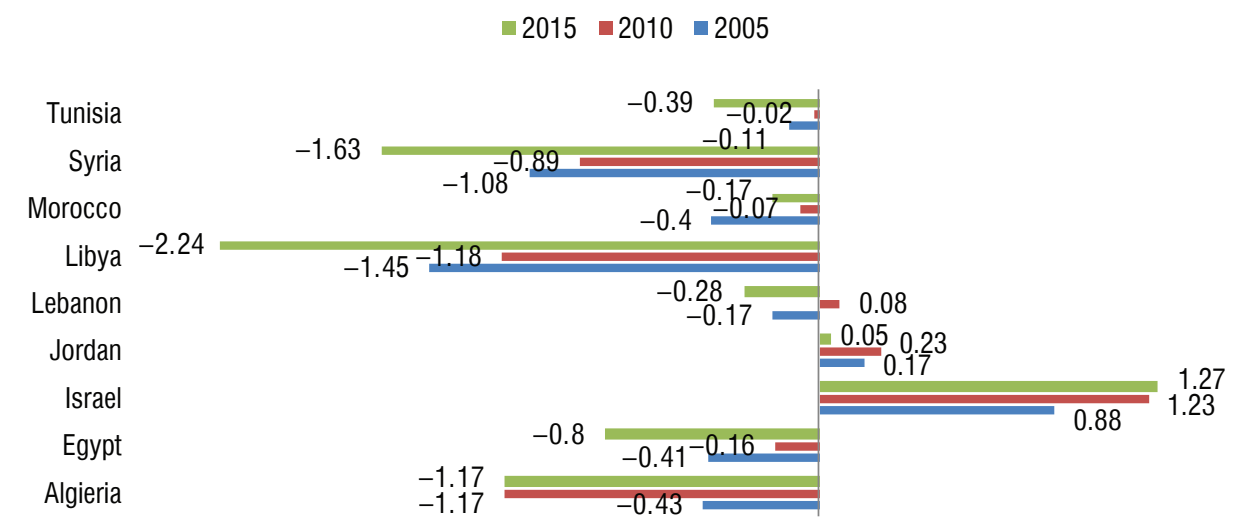

Source: own study based on the Indicator of Worldwide Governance http://info.worldbank.org/governance/ wgi/index.aspx\#home

Figure 5. Rule of Law

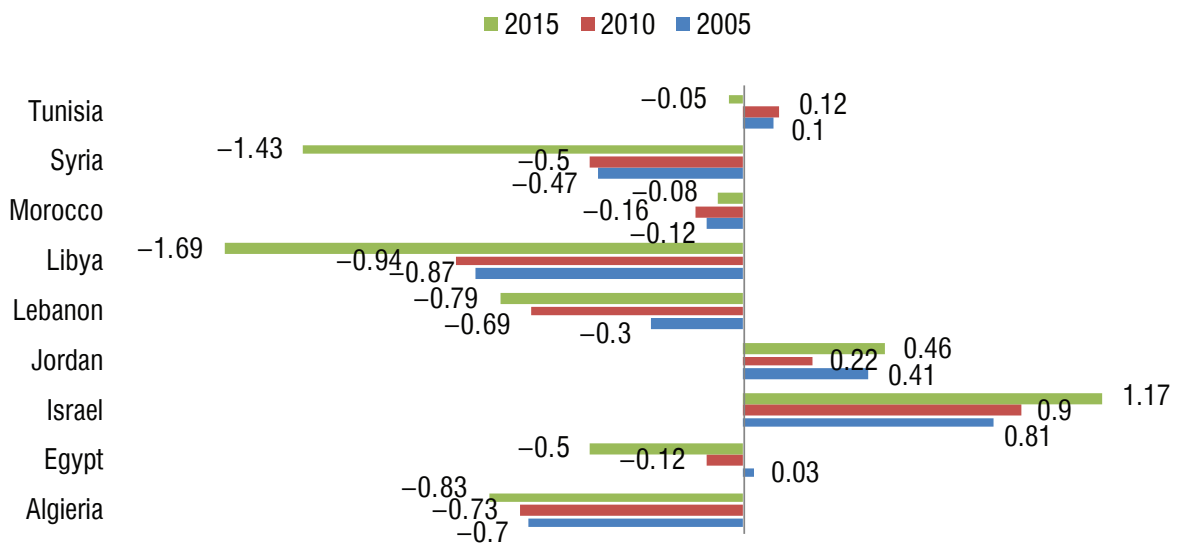

Source: own study based on the Indicator of Worldwide Governance http://info.worldbank.org/governance/ wgi/index.aspx\#home

When it comes to the last indicator, 'Control of Corruption' (Figure 6), it is a universal and predominant problem for all countries. However, best results have been found in Israel and Jordan. Morocco has also received relatively better outcomes than other countries. The vast majority of states could not manage the problem of corruption, nonetheless the focus was put on efforts undertaken by public and private institutions and entities. It is strongly related to the quality of the rule of law, the implementation and execution of internal legislation. 


\section{Figure 6. Control of Corruption}

$\because 2015=2010 \quad \square 2005$

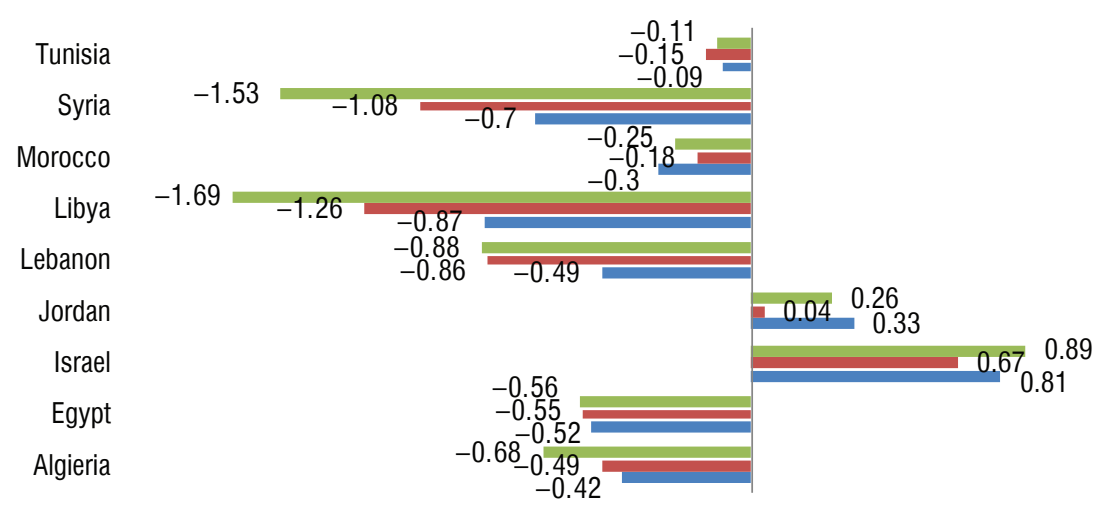

Source: own study based on the Indicator of Worldwide Governance http://info.worldbank.org/governance/ wgi/index.aspx\#home

The surveys show clearly that the Mediterranean countries covered by the ENP framework have large problem with meeting the goals related to governance. The exception was Israel ${ }^{26}$. Jordan has also been assessed much better against other countries. The worst situation was clearly noticeable in Libya and Syria. An important event that affected the process of changes in regulatory measures were the terrorist attacks of September $11^{\text {th }}$. The initiated liberalization of regulations was suspended and the process of pro-democratic changes was reversed in Morocco, Jordan, Egypt. The introduction of anti-terrorist legislation was a good opportunity to curtail political and civil liberties. The IWG estimations show some general tendencies in the perceptions of governance, which are reflected in other studies and research ${ }^{27}$.

\section{Expenditures and Outcomes}

After 12 years of implementation of the ENP, the results are not satisfying. Most of the partner countries which signed the individual ENP Action Plans have accepted

26 Israel has a special position within the framework of the ENP, which is not comparable to the relations of the Arab partner countries. European Commission, EU Neighborhood Policy, https://ec.europa.eu/ neighbourhood-enlargement/neighbourhood/countries/israel_en [access 9.03.2016].

27 M. Comelli, M.C. Paciello, A Cost/Benefit Analysis of the ENP for the EU's Southern Neighbours, [in:] G. Avery, Y. Nasshoven, The European Neighbourhood Policy: Challenges and Prospects, "Trans European Policy Studies Association" (TEPSA), Brussels 2008, pp. 59-78. 
the policy as a necessary framework they cannot escape if they want to continue their relations with the EU (Morocco, Jordan or Tunisia). Others have abandoned the Euro-Mediterranean partnership due to internal crisis and political tensions (Egypt, Libya, Algeria).

It is generally accepted that the positive results from the ENP Action Plans are selective and uneven ${ }^{28}$. Nevertheless, there is some progress in the Mediterranean countries which was evoked by the Action Plans priorities. These are symptoms of democratization or according to other terminology - governance improvement. The most common results are the political differentiation at the local level and limited development of gender rights. Some limited achievements in these areas were registered in countries such as Morocco, Tunisia, Jordan. Other basic premises such as democratic and transparent elections, restrain of corruption and media freedom are difficult to examine because they have varied from country to country over the past decades (some tendencies were presented in the previous section, see: Figure 1-5). The most advanced countries have introduced international conventions or amendments to their domestic law. For instance, in 2005 Morocco initiated legislation related to corruption, abolishment of torture and functioning of political parties. There were accepted international conventions on racial discrimination, children's rights and torture $^{29}$. Additionally, the government introduced a national plan on democratization and human rights. The plan was supported by a wide range of representatives from the government, private sector, NGOs and media. It strictly corresponded with the provisions included in the ENP Action Plan, which indicated that Morocco was seeking to fulfill its commitment towards the EU.

The general problem for all Mediterranean partners is that most of them have made little progress on reforms in line with the Action Plans and those most advanced have also introduced some restrictions. According to M. Comelli and M.C. Paciello changes in the Mediterranean countries were tenuous and shallow. It refers in particular to general or presidential elections, civil society rights and human rights. In most countries violations of human rights have even increased in recent years ${ }^{30}$. The domestic situation in the countries testified the truth that the introduction of changes in formal law did not translate into the real political and social life. Formal activities undertaken by the governments of selective Mediterranean countries have not brought substantial changes in their political systems.

\footnotetext{
28 A.K. Jonasson, The EU's Democracy Promotion and the Mediterranean Neighbours. Orientation, Ownership and Dialogue in Jordan and Turkey, Routledge, London 2013, pp. 181-198.

29 M. Comelli, M.C. Paciello, The ENP's Potential, op.cit., p. 54.

30 Ibidem, p. 55.
} 
The announcement of changes and improvement of the government have appeared nothing more than cosmetic mutations. Countries such as Morocco, Jordan, Tunisia or Egypt have managed to implement some pro-democratic changes but at the same time they reduced other liberties and rights. It means that there were not carried out genuine reforms which would be reflected in their social and political systems. In Morocco, the situation has deteriorated after the September $11^{\text {th }}$ and bombing attacks in Casablanca in 2003. As a result, the government has limited the freedom of association and assembly and freedom of expression as well as activities of opposition parties. Morocco also lacks an independence of judicial power, which would assure the introducing of democratic law. The whole power is centralized in the King's hands, thus all impetus for any reforms comes from the King's office and any ideas for changes must be supported by the ruling elite in Morocco.

A similar tendency is visible in Jordan. In 2005 the government released the National Agenda, which included social and political commitments. According to the document, a new anti-corruption law and provisions on greater women's participation in social and political life were accepted. A new Municipalities Law stipulates to provide a $20 \%$ quota for women in a municipal council ${ }^{31}$. There were also initiated some changes in the political party legislation and electoral law. Jordan is the only partner country whose Action Plan anticipates some reform in its electoral law. It is expected to be met, however, the content of the reform is unclear. In the area of freedom of expression, the parliament has abolished imprisonment as a penalty, but maintained a high fine for reporters and journalist. An improvement of an anti-terrorist act resulted in delimitation of political and civil liberties ${ }^{32}$.

Another example is Egypt. In 2007 president Mubarak introduced several constitutional amendments and at the same time put ban on functioning political parties based on religion or ethnicity ${ }^{33}$. The implementation of the Action Plan provisions finalized in 2007 was put at risk. In 2006 the country plunged into political turmoil. At that time, the ruling party was fighting with its opposition by approving some amendments which diminished judicial supervision of elections, banned political activity based on religion and gave the executive authority, specifically the president and the security forces, unprecedented powers ${ }^{34}$. All in all, the Arab Spring has changed the whole order of things. Some countries such as Egypt has enmeshed

\footnotetext{
31 Ibidem, p. 55.

32 Ibidem, p. 58

33 R. Pace, The European Neighbourhood Policy: The Southern Dimension, [in:] The European Neighborhood Policy and the Southern Mediterranean, eds. M. Comelli, A. Eralp, C. Ustun, Middle East Technical University Press, Ankara, Turkey 2009, p. 46.

34 M. Comelli, M.C. Paciello, The ENP's Potential, op.cit., p. 59.
} 
in domestic political strife, other have slid into the civil war or fallen prey to international military interventions (Libya, Syria). In consequence, the countries unable to perform its function have left the reforms and abandoned their moderate pro-democratic changes.

Moreover, the EU's expectations that higher growth rates and economic development would automatically stimulate political reform have not been met. The correlation between the state of governance and the economic performance has appeared to be very weak. Those countries who have achieved some progress in governance have managed to achieve better economic results. There was a slight progress for countries such as Tunisia, Morocco, Jordan, though there is much to catch up in comparison to the countries from Central Europe before their accession to the EU in 2004 and $2007^{35}$. For instance, in Tunisia, economic modernization proceeded quite fast but it was accompanied by an increase in corruption and the deterioration of authoritarian regime. The economic openness resulted in reinforced state interference in the private sector. ${ }^{36}$ In the countries such as Egypt, Morocco or Jordan, sluggish economic development coexisted alongside with the rebuilding of authoritarianism and persisting violations of human rights and fundamental freedoms.

\section{Conclusion}

The implementation of the ENP Action Plan by the Mediterranean governments has not led to genuine liberalization of the countries. Most activities in the area of democratization or governance are limited to technical changes in the public administration and formal legislation. The introduction of a new law does not mean effective transformation of the system. Although the governments in Jordan or Morocco have introduced numerous regulations in line with the ENP Action Plan, at the same time liberties and rights were reduced. It means that the pro-democratic changes in legal measures and political systems have not been followed by real actions and effective decisions. The general or presidential elections have continued to be formal exercises rather than open political competitions and human rights violations have increased.

35 L. Delcour, In Need of a New Paradigm? Rethinking the European Neighbourhood Policy/Eastern Partnership, "Eastern Partnership Review" No. 20, April 2015, p. 7; S. Casablanca, The Dilemma of the EU Neighbourhood Policy: Mediterranean vs. Eastern Partnership, "Readings - Eastern Europe in Brief" No. 3, April 2015, pp. 2-6; S. Blockmans, The ENP and 'More for More', op.cit., p. 56.

36 N. Tocci, J.P. Cassarino, Rethinking the EU's, op.cit., p. 4. 
The reason for the meager fulfillment of the ENP program is the lack of civil society and political pluralism, the lack of separation of powers, unstable electoral procedures. In all countries freedom of expression was restricted and electoral law remained in favor of the ruling party. A number of disappointing examples can be found in the most advanced countries in terms of proceeded reforms, which are Morocco and Jordan. Both countries fluctuate between the minimal necessity of political reforms and acts of repression. The monarchy retains its monopoly on power and all decisions are taken by institutions under the strong control of the regime.

The realization of the ENP's goal, which is the promotion of democratization and political stability, is much hindered by the fact that the ruling authorities in the Mediterranean countries are much more focusing on development of economic relations than introducing political changes. The political maintenance of the regime is conditioned to a large extent by economic development. More trade and investments can bring substantial benefits and pro-democratic changes in the long-run perspective. It is an objective of the DCFTA, which means a wider and better access to the European market for Mediterranean goods and a larger foreign direct investment inflow to the partner countries' markets.

Most of the Mediterranean countries balance between some political reforms and repression. The general concept is to introduce some political changes and maintain a good international image. The economic area and cooperation with the EU is based on a much more realistic approach and calculation. The governments are very much interested in developing trade and economic relations with the EU, since Europe is the biggest and strategic economic partner for most of the South Mediterranean countries. By contrast, the political area is strictly restricted to domestic ruling forces and no real reforms have a chance to be implemented. The authoritarian regimes agree only on those reforms which do not threaten the status quo and their dominant position. The EU financial support for the Mediterranean reforms is too small incentive to bolster the change needed to secure a successful transition from authoritarianism to democratic rule.

\section{Bibliography}

Aliboni R., Evaluating the Political and Strategic Dimensions, [in:] The European Neighbourhood Policy and the Southern Mediterranean Drawing from the Lessons of Enlargement, eds. M. Comelli, A. Eralp, C. Ustun, Middle East Technical University Press, Ankara, Turkey 2009. 
Blockmans S., The ENP and 'More for More' Conditionality: Plus Que ça Change ..., "Cleer Working Papers" 3, 2013.

Casablanca S., The Dilemma of the EU Neighbourhood Policy: Mediterranean vs. Eastern Partnership, "Readings - Eastern Europe in Brief" No. 3, April 2015.

Comelli M., Paciello M.C., Cost/Benefit Analysis of the ENP for the EU's Southern Neighbours, [in:] G. Avery, Y. Nasshoven, The European Neighbourhood Policy: Challenges and Prospects, "Trans European Policy Studies Association" (TEPSA), Brussels 2008.

Comelli M., Paciello M.C., The ENP's Potential for Reform in the Southern Mediterranean: A Cost/Benefit Analysis, [in:] The European Neighborhood Policy and the Southern Mediterranean, eds. M. Comelli, A. Eralp, C. Ustun, Middle East Technical University Press, Ankara, Turkey 2009.

Communication from the Commission to the Council, the European Parliament, the European Economic and Social Committee and the Committee of the Regions, Governance in the European Consensus on Development - Towards a Harmonized Approach Within the European Union, Brussels 30.8.2006.

Council of the EU, Council Conclusions on the ENP, 851st External Relations, Brussels, 18.02.2008.

Delcour L., In Need of a New Paradigm? Rethinking the European Neighbourhood Policy/ Eastern Partnership, "Eastern Partnership Review" No. 20, April 2015.

European Commission, EU Neighborhood Policy, https://ec.europa.eu/neighbourhoodenlargement/neighbourhood/countries/israel_en

European Commission, European Neighborhood Policy and Enlargement Negotiations, https://ec.europa.eu/neighbourhood-enlargement/neighbourhood/overview_en

European Commission, Trade Policy, http://ec.europa.eu/trade/policy/countries-and-regions/ countries/palestine/\#footnote-1

Ferrero-Waldner B., The European Commissioner for External Relations and European Neighbourhood Policy, The Middle East in the EU's External Relations, Madrid 11.01.2007, http://europa.eu/rapid/press-release_SPEECH-07-7_en.htm

Joint Communication to the European Council, the European Parliament, the Council, the European Economic and Social Committee and the Committee of the Regions, A Partnership for Democracy and Shared Prosperity with the Southern Mediterranean, $\operatorname{COM}(2011) 200$ final, Brussels 8.3.2011.

Jonasson A.K., The EU's Democracy Promotion and the Mediterranean Neighbours. Orientation, Ownership and Dialogue in Jordan and Turkey, Routledge, London 2013.

Kaufmann D., Kraay A., Mastruzzi M., The Worldwide Governance Indicators: Methodology and Analytical Issues, September 2010, http://info.worldbank.org/governance/ wgi/pdf/WGI.pdf

Koeth W., The 'Deep and Comprehensive Free Trade Agreements': An Appropriate Response by the EU to the Challenges in its Neighbourhood?, European Institute of Public Administration, 2014. 
Loo G., Enhancing the Prospect Sot the EU's Deep and Comprehensive Free Trade Areas in the Mediterranean: Lessons from the Eastern Partnership, Centre for European Policy Studies, CEPS Commentary, 24.06.2015.

Pace G., The Notion of Governance in the South Mediterranean Regions, http://www.cnr.it/ istituti/Allegato_47006.pdf?LO...

Pace R., The European Neighbourhood Policy: The Southern Dimension, [in:] The European Neighborhood Policy and the Southern Mediterranean, eds. M. Comelli, A. Eralp, C. Ustun, Middle East Technical University Press, Ankara, Turkey 2009.

Sarto R.A., Schumacher T., From EMP to ENP: What's at Stake with the European Neighbourhood Policy Towards the Southern Mediterranean?, "European Foreign Affairs Review" 2005.

Tocci N., Cassarino J.P., Rethinking the EU's Mediterranean Policies Post- 1/11, "IAI Working Papers" No. 11/06, Istituto Affari Internazionali, 6.03.2011.

Worldwide Governance Indicator, http://info.worldbank.org/governance/wgi/index. aspx\#home

Wouters J., Duquet S., The Arab Uprisings and the European Union: In Search of a Comprehensive Strategy, "Cleer Working Papers" 3, 2013.

\section{External and internal liberalization that ENP promotes as transmission belts of democratization and political stability: success and failure revisited - the Southern Dimension}

The European Neighborhood Policy (ENP) was launched in 2004 with the aim of building new political and economic relations between the EU and its Southern and Eastern neighboring states through support for introduction of reforms and systemic changes in the partner states. In the South, the initiative covered ten countries: Algeria, Egypt, Israel, Jordan, Lebanon, Libya, Morocco, Palestine, Syria and Tunisia. It was associated with better political and economic relations with the EU, which should result in a wider access to the European market for Mediterranean goods and a larger foreign direct investment inflow to the partner countries' markets.

The aim of the paper is to analyze the effects of ENP on the Southern Mediterranean neighbors in the context of economic liberalization and pro-democratic changes. The paper analyses two problems: economic development and trade liberalization offered by ENP through deeper integration with the EU and marketoriented regulations. The second problem analyzed in the paper concerns the process of democratic changes that the EU committed to promote. Due to the highly controversial nature of democratization for the Mediterranean states, it 
was replaced by the idea of good governance. For this purpose, general trends within the Mediterranean societies in their approach to that notion of governance are presented.

Keywords: European Union (EU), European Neighborhood Policy (ENP), Union for the Mediterranean (UfM), Deep Comprehensive Free Trade Agreement (DCFTA), governance, democratization.

\section{La libéralisation externe et interne que la PEV présente comme courroies de transmission de la démocratisation et de la stabilité politique: les succès et échecs revisités - cas des pays du Sud ${ }^{37}$}

La politique européenne de voisinage (PEV) a été lancée en 2004 dans le but de construire de nouvelles relations politiques et économiques entre l'UE et ses pays voisins au sud et à l'est grâce au soutien de l'introduction des réformes et des changements systémiques dans les pays partenaires. Dans le cas des voisins du sud, l'initiative concernait dix pays: Algérie, Egypte, Israël, Jordanie, Liban, Libye, Maroc, Palestine, Syrie et Tunisie. L'initiative en question a été également associée à de meilleures relations politiques et économiques avec l'UE ce qui devrait aboutir à un accès plus large au marché européen pour les produits méditerranéens, ainsi qu'à une augmentation du nombre d'investissements étrangers directs dans les pays partenaires.

Le but de cet article consiste à analyser les effets de la PEV sur les voisins méditerranéens par rapport à la libéralisation économique et aux changements pro-démocratiques. L'article aborde deux questions. La première concerne le développement économique et la libéralisation des échanges que la PEV rend possibles grâce à une plus forte intégration avec l'UE et une réglementation axée sur le marché. L'autre question concerne le processus de changements démocratiques que l'UE s'est engagée à promouvoir. Compte tenu que les pays méditerranées sont très sensibles à la notion de démocratisation, celle-ci a été remplacée par l'idée de la gouvernance. A cet effet, l'auteur tente de présenter les tendances générales dont les sociétés méditerranéennes font preuve en ce qui concerne la notion de gouvernance.

\footnotetext{
37 Le document a été préparé dans le cadre de la subvention de recherche du Centre national de la science polonaise $(\mathrm{NCN})$ intitulé «La politique européenne de voisinage: la gouvernance à plusieurs niveaux, le processus de réforme et la perspective d’une coopération renforcée dans la région, OPUS/HS5, n 2013/09/B/ HS5/04534.
} 
Mots-clés: Union européenne (UE), politique européenne de voisinage (PEV), Union pour la Méditerranée (UpM), Accord de libre-échange complet et approfondi (ALECA), gouvernance, démocratisation.

\section{Внешняя и внутренняя либерализация, продвигаемая ЕПС, как механизм трансфера демократизации и политической стабильности: успехи и неудачи. Южное измерение}

Европейская политика соседства (ЕПС) была начата в 2004 году с целью создания новых политических и экономических отношений между ЕС и его южными и восточными странами-соседями посредством поддержки реформ и внедрения системных изменений в странах-партнерах. На юге инициатива охватывала десять государств: Алжир, Египет, Израиль, Иорданию, Ливан, Ливию, Марокко, Палестину, Сирию и Тунис. Это было связано с хорошими политическими и экономическими отношениями с ЕС, что должно было привести к более широкому доступу средиземноморских товаров к европейскому рынку и увеличению притока прямых иностранных инвестиций на рынки стран-партнеров.

Целью статьи является анализ влияния ЕПС на южных средиземноморских соседей в контексте экономической либерализации и про-демократических перемен. В работе рассматриваются две проблемы. Во-первых, вопрос экономического развития и либерализации торговли, что предлагает ЕПС посредством углубления интеграции с ЕС и внедрения рыночных правил. Вторая дилемма касается процесса демократических преобразований, которые ЕС намерен продвигать. Из-за крайне чувствительного подхода средиземноморских государств к концепции демократизации она была заменена идеей управления. Поэтому были представлены основные тенденции, присутствующие в средиземноморских обществах в отношении понятия управления.

Ключевые слова: Европейский Союз (ЕС), Европейская политика соседства (ЕПС), Союз для Средиземноморья (СдС), Углублённая и всеобъемлющая зона свободной торговли (УВЗСТ), управление, демократизация. 